\title{
Individuals And Society in Liquid Modernity
}

\section{Suzan Sabri}

Department of Sociology, College of Law and International Relations, French Lebanese University, Erbil, Kurdistan Region

suzan.sabri@lfu.edu.krd

\section{ARTICLE INFO}

\section{Article History:}

Received: $12 / 4 / 2021$

Accepted: 25/5/2021

Published: Summer 2021

Keywords: $\quad$ Liquid

Modernity,

Globalization, Zygmunt

Bauman, Society

Doi:

10.25212/lfu.qzj.6.3.35

\section{ABSTRACT}

Liquid modernity might be a new concept for many. According to sociologist and philosopher Zygmunt Bauman, modern society is melting and becoming fluid as he defines the latter as Liquid modernity. In his work, Bauman analyses the disappearance of solid structures and institutions that formed the foundation of modern society in which they are increasingly making way for processes that are constantly changing. In addition, this fluid world never retains the same shape for long and is characterized by never standing still. Everything seems to change: the fashion we follow, the technology we use, and the things we dream of. This results in constant uncertainty and fear of what the future holds. This new order, which is a continuation of modernity in a different form offers opportunities. Especially, that current time and place are losing relevance due to technological developments and in this way the world is at the feet of the fluid individual. Bauman labels the latter as 'change is the only constant and uncertainty is the only certainty' (Bauman, 2012). The aim of this study is to elaborate the above stated changes that affect individuals and society in terms of becoming fluid. Besides, it is worth mentioning that identities are complex and constantly changing. Complexity influences the power and politics in modern societies in relation to the globalized era. In other words, there is an increasing gap between the ability to act effectively (power) and the ability to decide what should be done (politics). 


\section{QALAAI ZANISTSCIENTIFIC JOURNAL \\ A Scientific Quarterly Refereed Journal Issued by Lebanese French University - Erbil, Kurdistan, Iraq \\ Vol. (6), No (3), Summer 2021 \\ ISSN 2518-6566 (Online) - ISSN 2518-6558 (Print)}

\section{INTRODUCTION}

\subsection{The Problem Statement}

Nowadays, academics, politicians and social thinkers agree that modernization discourse has been dominant in the Middle East. In transition from traditions to modernity, the Kurdish society has gone through noticeable changes. These changes causes changes in power and politics between individuals within society. The problem statement of the study argues about the increasing gap between the ability to act as citizen and the ability to decide as government due to liquid modernity process. The work of Zygmunt Bauman on liquid modernity is very often chosen as an appropriate lens for viewing the political and governance issue with a strong spatial dimension within society. Bauman seeks to highlight on an important shifts in contemporary society that introduce the dominant political and economic paradigm at international level. He is particularly concerned with spatial economic differences and inequalities. This study is offering an analysis by Zygmund Bauman of events and conditions from the global to local individuals, which has been useful in the sense of not excluding one or the other but rather the integration of both into the same analysis.

\subsection{The Research Questions}

Bauman extends not only the political and economic framework but he also discusses how individuals make and remake their lives in response. A set of research questions is formulated to draw out the connection between society, local individuals and globalization through the lens of the concept of liquid modernity.

Therefore, this study is structured around ways of finding answers to one main research question, namely; is Bauman's concept of liquid modernity useful enough to analyze the globalization impact on society and local individuals? Accordingly, the following sub-questions will tackle the underlying elements of the main question:

1. What is the connection between liquid modernity and society according to Zygmund Bauman?

2. What is known about globalization and liquid modernity from the perception of Zygmund Bauman? 


\section{QALAAI ZANISTSCIENTIFIC JOURNAL \\ A Scientific Quarterly Refereed Journal Issued by Lebanese French University - Erbil, Kurdistan, Iraq \\ Vol. (6), No (3), Summer 2021 \\ ISSN 2518-6566 (Online) - ISSN 2518-6558 (Print)}

3. What kind of changes in society will happen through the concept of liberation according to Zygmund Bauman?

\subsection{The Aim}

This study aims to introduce and analyze the concept of liquid modernity and globalization by Zygmunt Bauman. Firstly, the analysis of late modernity by the British-Polish philosopher-sociologist Zygmunt Bauman will be discussed. He characterizes the current socio-economic area through a word taken from the field physics. The concept of liquid modernity refers to the relative free flow of people, money and ideas around the world. Bauman uses the term liquid to point to something that is 'melting'. According to him, in a society, people, money and ideas melt because of being dissatisfied concerning the general claim of truth (Hall, Held, and McGrew, 1992).

However, presently speaking, The western society remains burdened with the most influential phenomenon of these days, namely globalization. The latter is most usually discussed theoretically, however, it is least unambiguous concepts of today, both in technical terminology as in the media and in our everyday language. For a basic understanding of globalization, the book "A Global Society?" written by Anthony McGrew (1992), will be used for the purpose of analyzing the mentioned concept. Additionally, this study consists of two parts; on the one hand, theoretical explorations that deal with Bauman's concept of 'liquid modernity', and on the other hand it will discuss the phenomenon of globalization and the changed relationship between individuals and community.

\subsection{Social Relevance}

Regarding the social relevance of the current study, the concept of modernity is associated with globalization that started from the twentieth century as modern endeavor and later it became a progressively global phenomenon. However, modernity was primarily a project of the West, which distanced itself from the rest of the world while the West frequently excluded, colonized and exploited the 'others' however the term others may be interpreted. After all, the Western world wanted to become modern from the start by making unions of their areas, like the European 


\section{QALAAI ZANISTSCIENTIFIC JOURNAL \\ A Scientific Quarterly Refereed Journal Issued by Lebanese French University - Erbil, Kurdistan, Iraq \\ Vol. (6), No (3), Summer 2021 \\ ISSN 2518-6566 (Online) - ISSN 2518-6558 (Print)}

Union (EU). The latter happened especially when the labor market principles were disturbed.

Additionally, the process of globalization evolved gradually as it become one of the many rapid developments worldwide. So, globalization acted entirely as an economic force that impacted the political progression of nation-states and the social separation between private and public sectors. This power shift from public sectors to private sectors has caused a lack of political manageability which is resulted in less relevant of politics due to the absence of political power within a society. Thus, politics and power are separated from each other due to the global force.

Besides, the changes in local societies have appeared as a result of fundamental global problems that do not permit local solutions. All in all, it is relevant for the Kurdish society to understand the impact of modern changes and developments on people. However, it is worth to mention that many aspects of modern-day in the Kurdish society remain unexplored and unexplained.

Despite of the lack of information regarding the modern Kurdish society, it can not be denied that Kurds in the Kurdistan Region of Iraq are living in a period dominated by rapid cultural and social changes. The stated changes are; a deep crisis of established values, and the initiatives of a little elite groups that somehow control the society. On the other hand, modernization basically means to change a cultural system to a new mode. Thus as Zygmund Bauman points out; moving away from a 'heavy' and 'solid', hardware-focused modernity to a 'light' and 'liquid', software-based modernity.

\section{THE WORK OF ZYGMUNT BAUMAN}

Zygmunt Bauman was born in 1925 in Poland and grew up in a society under the authority of the Soviet Union state. His first work shows his primary interest in social stratifications, which was reflected in 1964 in a debate that was entitled Sociology for Everyday Life. As a sociologist, he interprets human actions as elements within a greater whole of mutual dependency. He pleads for a world that is more open to individual and collective freedom, but at the same time, he is aware of the consequences of increasing human freedom and the destabilization of existing power relations.

In his work, Bauman also argues the German philosophers and sociologists Karl Marx 


\section{QALAAI ZANISTSCIENTIFIC JOURNAL \\ A Scientific Quarterly Refereed Journal Issued by Lebanese French University - Erbil, Kurdistan, Iraq \\ Vol. (6), No (3), Summer 2021 \\ ISSN 2518-6566 (Online) - ISSN 2518-6558 (Print)}

and Jürgen Habermas and the Italian politician Antonio Gramsci influenced his thinking from the 1970s onwards, leading Bauman to himself as a social philosopher emerged. Bauman is convinced that " to understand the world, human beings have to regain control over it" (Smith, 1999 p.5). However, Bauman maintains the use of philosophical concepts such as equality, freedom, and justice, but he considers them as typical Western and as enlightened values. Moreover, his interest shifted from the early 1980s to the phenomena "modernity" and "globalization", about which he wrote more than twenty works. After the attack of 9/11, he describes the excesses of late modern society (Smith, 1999). According to Dennis Smith who was the biographer of Zygmunt Bauman, he describes in his book, wherein he describes Bauman as Prophet of Postmodernity (1999). The latter describes that common threads can be found in Bauman's work. On the one hand, the narrative progresses towards a social utopia, regards his early work, and on the other hand a later work of Bauman that deals with the transition from modernity to fluid modernity (Smith, 1999).

Furthermore, most of Bauman's work begins with the breakdown of traditional social order, such as heroes or pioneers, and ends by challenging the reader to take some action or make some choices. The latter, where Bauman asks his readers to act or make a choice regarding the themes he cited, makes him not only a sociologist and philosopher but also a storyteller. Moreover, he does not strive for absolute clarity or a ready-made theory but wants to make the readers think. As a neo-Marxist, he prefers dialectics as a methodology (Smith, 1999).

\subsection{CONCEPTION OF LIBERATION BY ZYGMUND BAUMAN}

Bauman discusses in his book the concept of liberation. What does liberation mean? Most people don't see the need to be liberated from society, and of those that do, relatively few are prepared to take action towards liberation, and most of those have little idea of how a more liberated future might be different from our current situation (Alleva, 2012).

However, Bauman discusses the conception of liberation by noting that "to feel free means to experience no hindrance, obstacle, resistance or any other impediment to the moves intended or desired" (Bauman, 2012, p.30). Besides, he argues that feeling free from constraint means finding a balance between one's wishes (or imagination) 


\section{QALAAI ZANISTSCIENTIFIC JOURNAL \\ A Scientific Quarterly Refereed Journal Issued by Lebanese French University - Erbil, Kurdistan, Iraq \\ Vol. (6), No (3), Summer 2021 \\ ISSN 2518-6566 (Online) - ISSN 2518-6558 (Print)}

and the stubborn indifference of the world to one's intentions. And this balance might be achieved in two ways, through either expanding one's capacity to act or through limiting one's desires (imagination).

Now the questions are being exposed by Bauman are about feeling free or freedom. Firstly, why has freedom been slow to arrive? Secondly, when freedom does arrive, why is it so often seen as a curse? Bauman explains one type of answer to the first question, which is that men are not ready for freedom. However, these kinds of responses are usually accompanied by either pity for the men who are duped from their freedom, or anger at the masses who are unwilling to take up their freedom. Moreover, Bauman argues that another attempt to answer this question is that the culture industry which makes us thirst for entertainment rather than spiritual fulfillment (Bauman, 2012).

The possible answer to the second question is that men are not prepared to face liberty because of the hardships it brings. However, this answer criticizes the libertarian notions of freedom. The latter, explained by Charles Murray, explains that happiness is related to individual resourcefulness, and what fills an event with satisfaction is that ' $\mathrm{l}$ ' did it. Moreover, Bauman disagrees with him and points out that counting on yourself too much predicts fear of risk and failure without the right to appeal and seek a story. Furthermore, Bauman is in line with the legacy of Durkheim to argue that we are right to be skeptical about the benefits of libertarian notions of freedom. He seems to show sympathy with the Durkheimian idea that a degree of social coercion is an emancipatory force. To quote Durkheim:

"The individual submits to society and this submission is the condition of his liberation. For man freedom consists of deliverance from a blind, unthinking physical forces; he achieves this by opposing against them the great and intelligent force of society, under whose protection he shelters. By putting himself under the wing of society, he makes himself also, to a certain extent, dependent upon it, But this is a liberating dependence, there is no contradiction in this" (Cladis, 1989).

In other words, there is no way to achieve freedom other than to submit to the norms of society, and the individual needs society to be free. However, a total freedom society means indecision and uncertainty about the will of those around you, whereas 


\section{QALAAI ZANISTSCIENTIFIC JOURNAL \\ A Scientific Quarterly Refereed Journal Issued by Lebanese French University - Erbil, Kurdistan, Iraq \\ Vol. (6), No (3), Summer 2021 \\ ISSN 2518-6566 (Online) - ISSN 2518-6558 (Print)}

patterns and routines condensed by social pressures give us road markings, inform us how to act, and give us a sense of certainty in this life.

\subsection{LIQUID MODERNITY}

Zygmunt Bauman advocates for the idea of liquid modernity. This view emphasizes the fact of change within society, and it argues that change is occurring more and more rapidly in the "modern" world.

\subsection{DIALECTICS: "SOLID MODERNITY" VERSUS "FLUID MODERNITY"}

This section argues solid modernity and fluid modernity. In his book about liquid modernity, Bauman (2012) does not use "postmodernity" in a context, but resolutely opts for "liquid modernity". He does not give an exact definition, instead, he explains the concept. However, Bauman borrows the term "liquid" from physics; there it is generally known that substances in three prevent different aggregation states of phases; huge, liquid or gaseous. The liquid and gaseous substances differ from the solid in that they do not have a shearing force (Bauman, 2012, p.1). Also, he argues that these substances are subject to a "continuous change in shape when exposed to such stress"(Bauman, 2012, p.1).

Furthermore, Bauman explains in his book that liquid substances cannot be characterized in a specific spatiotemporal context, while solid forms are very clearly delineated in time and space. He points out an example of being a temperature below zero degrees Celsius, water appears in its solid form: like ice. The molecules sit in a fixed place, attract each other, and hardly move. In this way, we can shape the volume of an ice cube as it no longer changes.

So it becomes, as the certainties in the solid modern era where it becomes supertemporal and universal. Also, liquids, on the other hand, attach great importance to the transience of the concept of time as they wave as it were at a constant flow of time. However, Bauman does not state why he does not choose "gaseous" instead of "liquid" modernity (Bauman, 2012).

Regarding the use of the term "fluid" Bauman argues that "In the liquid state, the parts are still close together, but the regularity has disappeared. The parts move crisscross through each other and hold each other much less firmly" (Bauman, 2012). 


\section{QALAAI ZANISTSCIENTIFIC JOURNAL \\ A Scientific Quarterly Refereed Journal Issued by Lebanese French University - Erbil, Kurdistan, Iraq \\ Vol. (6), No (3), Summer 2021 \\ ISSN 2518-6566 (Online) - ISSN 2518-6558 (Print)}

In short: by analogy with liquids, the old certainties are still present, but no longer in their original steadfast form. The constant mutual shifts between the molecules refer to the 'old' certainties that are under discussion in the current era. The main difference between solid and liquid modernity is, according to Bauman, one changing relationship between time and space: time and space compression, by removing the spatial and temporal distances (Bauman, 2012).

Furthermore, solid modernity appears when time and space are detached from the practice of life and each other. They then become multi-usable as categories of strategy and actions. For example, when persons move through places becomes a matter of human ingenuity, imagination, and ingenuity, this speed at which it happens is associated with the changing relationship between time and place.

However, the speed of changing the relationship between time and place does not have to sound strange. After all, the improvement of technology and mobility turned out to be major projects in modern times. Moreover, according to Scholars as Barker or Foucault time plays the most crucial role in solid modernity, as in societies the guards (often who have power) were masters over time as they immobilized the rest of the residents (Bauman, 2012, p.9). Moreover, in liquid modernity, time and space are no longer quantifiable, partly because of the virtual world in which we can fly easily and texting whit each other in every place of the world. Besides, the territorial, urban, and architectural space in fluid modernity has dedicated place to 'cybernatting space' that reached the world wide web as far as possible to share information (Bauman, 2012).

Due to the "time/space compression," the way of warfare is also being changed. In the post-panopticon era, power relations are changed in the sense that nowadays, war is no longer about conquering new areas, but the demolition of the walls trying to stop the flood of new global powers: so war seems strong on promoting global free trade in areas other than territorial (Bauman, 2012). Changed the relationship between time and space also entails another way of living together. For example, time and space are of secondary importance in the economic domain. Looking at the logic of a consumer-oriented economy, customers are getting excited about new things, experiences, and so on. 


\section{QALAAI ZANISTSCIENTIFIC JOURNAL \\ A Scientific Quarterly Refereed Journal Issued by Lebanese French University - Erbil, Kurdistan, Iraq \\ Vol. (6), No (3), Summer 2021 \\ ISSN 2518-6566 (Online) - ISSN 2518-6558 (Print)}

All in all, according to Zygmunt Bauman we live in a "Liquid Modernity". It can be written that liquid modernity is when romantic love affairs are entered easily and they are ended also easily. Nowadays, it can be noticed that the networks have taken the place of partners. Moreover, our lives require us to be flexible and willing to adjust our strategy at any time, and exchange loyalties. This adjustment can cause uncertainty. Moreover, this uncertainty that we see today is accompanied by a permanent fear wherein social and physical boundaries disappear. Therefore, people try to draw their own boundaries. People build fortress Europe or settle in "gated communities". The permanent insecurity in which we live is expressed as a fear of people who are strange or different. Liquid modernity takes on solidification forms, guaranteeing fluidity for those insides, but firmness and hardness for the strangers outside. Because it is not possible to get a grip on a liquid world, we try to cling to things that we can influence. However, the measures we take to this end miss the point: our compulsive attempts to create fixed boundaries are only a symptom of our powerlessness in the face of global problems.

\section{GLOBALIZATION}

This section focuses on the understanding of the concept of globalization, the impact of globalization on the nation-state, and the globalization and humanity model.

\subsection{A BASIC UNDERSTANDING OF GLOBALIZATION}

Globalization is one of the most commonly used concepts today, both in sociology and in the media and everyday language use. At the same time, it is therefore also one of the least unambiguous concepts. McLuhan 1964 argues that the globe is no more than a village (Mcluhan, 1964, p.20).

Marshall McLuhan, popularized in his successful book Understanding Media (1964), gives a clear interpretation of the term: through the development of technology and transport, among other things today we are in contact with the whole world; the world has become a village, as it were. Long before the global and the local were interconnected via the internet, among other things, McLuhan already used the concept when referring to the global reach of interpersonal relationships. Moreover, according to Hall, Held \& McGrew (1992) a leading British sociologist Anthony 


\section{QALAAI ZANISTSCIENTIFIC JOURNAL \\ A Scientific Quarterly Refereed Journal Issued by Lebanese French University - Erbil, Kurdistan, Iraq \\ Vol. (6), No (3), Summer 2021 \\ ISSN 2518-6566 (Online) - ISSN 2518-6558 (Print)}

Giddens argues that the phenomenon of "globalization" refers to: "acting and living (together) over distances, across the separate worlds of national states, religions, regions, and continents" (Hall, Held \& McGrew, 1992).

Furthermore, the scholar McGrew associates the concept of modernity with globalization: from the twentieth century onward, modern pursuit became "a progressively global phenomenon (Hall, Held \& McGrew, 1992).

The latter, argues that modernity was primarily a project of the West, which distanced itself from the rest and the frequently excluded, conquered, colonized, and exploited others. After all, Europe and America wanted to become modern from the start by forging alliances about their areas, especially concerning market principles. Yet the process of globalization evolved gradually, as it was initially just one of many developments. So acted globalization merely as an economic force, in addition to, for example, the political evolution of nations to nation-states or the social separation between the private and the public (Hall, Held \& McGrew, 1992).

Thus, globalization is a driving process since the earliest stages of the modern era and it is present and has shaped and reformed all spheres of society for a century. Besides, according to Bauman globalization is transforming the existing world order most conspicuously through its direct challenge to the primacy of the nation-state in its present form. He also argues that a society today is no longer a coherent whole because today they are both local as global influences, which is knowing as the wellknown phenomenon of "glocalization".

Therefore, globalization is primarily concerned with a condition "in which patterns of human interaction, interconnectedness, and awareness are reconstituting the world as a single social space" (Hall, Held \& McGrew, 1992, p.63). Also, the latter desire for connectedness between nations rather than within a nation, as this is attributed to include the global economic recession, the increasing threats of nuclear attacks in the conflict between the Soviet Union and America, and the terrifying ecological crisis 1980s. However, the rise of electronic media also creates a sense of a globally shared community. The concept of "globalization" has crept into the discourse on this since the 1980s changing the socio-economic context within the growing alliance between nation-states. Bauman (1992) points out that the gap between time and space is 


\section{QALAAI ZANISTSCIENTIFIC JOURNAL \\ A Scientific Quarterly Refereed Journal Issued by Lebanese French University - Erbil, Kurdistan, Iraq \\ Vol. (6), No (3), Summer 2021 \\ ISSN 2518-6566 (Online) - ISSN 2518-6558 (Print)}

created by the phenomenon of globalization, economic, and technological developments ensured the compression of time and space.

Furthermore, globalization concerns the intersection of presence and absence, the interlacing of social events and social relations "at a distance" with local contextualities. Having events, decisions, and actions on one side of the world which have an impact on the people and communities on the other side of the world about territorial borders. This causes the interaction between states and communities. Thus, globalization connects in the sense that "everyone has a local life, phenomenal worlds for the most parts are truly global" (Bauman, 1992).

\subsection{THE IMPACT OF GLOBALIZATION ON NATION-STATE}

This paragraph focuses on the role of globalization on the various aspects of this "tripod of military, economic, and cultural sovereignties. I will discuss their impact separately per section.

The first section concerns the political and military policies of a nation-state that aim at its borders to safeguard against enemies. The power once held by the nation-states has now been transferred to the global atmosphere, while politics remains reasonably local and is unable to interfere on a global scale. Responsibility for solving the community's problems now ends up on the shoulders of the individual, who will reunite himself in a kind of "reborn community" due to the "time and space compression". Also, the way of war is changed: power is no longer within reach, but out of state. There are no obvious places to occupy and so the state must read its military rule in different ways (Bauman, 2012).

The change from the concept of "power" to liquid modernity is a consequence of globalization. In solid modernity, progress was still based on the transition from a nomadic towards a sedentary society in which means that the conquest of the territory is the highest form of power. Nowadays, it is different because the game of domination in the era of liquid modernity is not played between the "bigger" and the "smaller", but between the quicker and the slower " (Bauman, 2012 p. 188).

Therefore, according to Bauman (2012), the nomadic man is powerful because he is mobile and can move freely and quickly to where he wants. However, the latter limits 


\section{QALAAI ZANISTSCIENTIFIC JOURNAL \\ A Scientific Quarterly Refereed Journal Issued by Lebanese French University - Erbil, Kurdistan, Iraq \\ Vol. (6), No (3), Summer 2021 \\ ISSN 2518-6566 (Online) - ISSN 2518-6558 (Print)}

himself to dividing tasks among the local authorities instead of taking over their duties, and if they refuse to maintain local order, they seize global with economic measures.

Furthermore, Bauman (2012) argues that the military rule is changing the war style, force is only used to harm the other because "involvement" is precisely what the wars aimed to "promote globalization by other means. Bauman (2012) shows an example of America, writes in his book that the war in Iraq started in 2003 and America where mainly intervened militarily does not answer the theory that avoided the direct involvement in the global era, and this led to a conflict. As a result, the Iraq War is perceived as a failure in the various US and foreign media, which is a testament to the fact that US interference from Iraq is not considered the best possible option for gaining power. CNN reporter Hans Blix calls the Iraq war "a terrible mistake" and is even afraid of the future: "I fear nothing is stopping this kind of tragedy from being repeated" (CNN, 2013). Another report that was published on March 20, 2007, points out that $51 \%$ of the British military sees the intervention in Iraq as a mistake (Bauman, 2012).

Next, Bauman argues that the impact of the global's on the locals is suffocating because there are local walls between them. The latter is located and fixed. The locals admire the globals but do not realize that the latter is their power by showing their way of life to the local people, without giving them the opportunity offered to imitate this way of life for themselves.

Moreover, power has no longer to do with submission and imposition of discipline but with adoration and seduction. The second task that states no longer can perform properly nowadays, is to preserve a dynamic balance between the growth rate of consumption and the increase of productivity. These days, states have no longer control over that balance because it is practically impossible to maintain a distinction between the internal and the global market (Bauman, 2012).

Next, the global laws and regulations dominate those of the nation-states rather than vice versa, which leads often to the downfall of economic sovereignty. Economy and politics are now separated from each other and every attempt by politicians to 


\section{QALAAI ZANISTSCIENTIFIC JOURNAL \\ A Scientific Quarterly Refereed Journal Issued by Lebanese French University - Erbil, Kurdistan, Iraq \\ Vol. (6), No (3), Summer 2021 \\ ISSN 2518-6566 (Online) - ISSN 2518-6558 (Print)}

revalue the economic domain would be with rapid and furious punishment from world markets (Bauman, 1998 p.51).

Yet, Bauman discusses in his book that the disintegration between economics and politics has become inevitable: it is going today in two separate domains with their laws and regulations. The last of the three tasks that nation-states must attempt to carry out to acquire power concerns "the ability to muster enough cultural resources to sustain the state's identity and distinctiveness through the distinctive identity of its subjects" (Bauman, 1998 p.62). Also, Bauman does not elaborate on this but argues that globalization, in general, has a huge impact on all aspects of its life.

\subsection{A NEW MODEL OF SOCIETY: GLOBALIZATION AND HUMANITY}

Nowadays people strived for a cosmopolitan society model from the enlightenment in which transnational covenants and universal values and norms such as peace, justice, freedom, and so on formed the conditions of human existence. This universal pursuit an interstate connection from solid modernity and this is no longer possible in liquid modernity. The latter is because change is one of the basic parameters of modern social life that no longer lies on the goal but on the initiatives and consequences associated with that goal. Bauman explains the rise and success of globalization through the loss of power, modern nation-states, and the upgrading of individuals (Bauman, 1998).

However, Bauman's views of society can be divided into four common ones in literature models of globalization, which may or may not attempt to adjust globalization and humanity in a new concept of society. The first model is provided by the social psychologist Saul Perlmutter, who believes that the increasing universalism of modernity is leading to "a global civilization" or "a world society" (Bauman, 1998 p. 66). However, humanity is seen as a community of fate. A universal community that is the subject that suffers from fate. Moreover, he does not equate globalization with westernization but views the phenomenon as a complex process regarding the change within western societies. This was caused by the merging of non-Western values and social practices. Besides, this leads to creating a kind of 


\section{QALAAI ZANISTSCIENTIFIC JOURNAL \\ A Scientific Quarterly Refereed Journal Issued by Lebanese French University - Erbil, Kurdistan, Iraq \\ Vol. (6), No (3), Summer 2021 \\ ISSN 2518-6566 (Online) - ISSN 2518-6558 (Print)}

global intercultural and pluralistic society that deviates itself from the traditionally ordered and nationalist society (Bauman, 1998 p. 67).

Furthermore, McGrew (1992) views the dialectical nature of globalization as a symptom of its unequal distribution in the world. Also, Bauman (1998) formulates the latter in a more nuanced way in his book Globalization: The Human Consequences, according to him entire planet is indeed subject to the forces of globalization but this does not imply the existence of a global unity or society. He points out that the globalizing processes lack the commonly assumed unity of its effects. Herein, he talks about a 'worldwide restratification' (Bauman, 1998 p.70). This restratification is due to unequal access to technology and the economy, the rich are getting richer and twothirds of the world's population remains poor.

The global communication network is also used selectively. Bauman quotes John Kavanagh, a policy officer in Washington: "Globalization is a paradox: while it is very beneficial to a very few, it leaves out or marginalizes two-thirds of the world's population" (Bauman, 1998 p. 71).

Although, the scholar Bauman also argues that national societies can no longer be viewed as highly structured and integrated spaces. A split has also developed within society: namely between a globalized elite and another group that remains locally bound. This dichotomy is expressed in a second model that puts a capitalist secular society first. Social geographer David Harvey and neo-Marxist thinker Fredric Jameson equate the increasing power of capital with "an increasing penetration and consolidation of capitalist social relations on a global scale" (Bauman, 1998 p. 71).

At the same time, Bauman (1998) recognizes that capitalist society is disintegrating into those who are part of transnational capitalism and on the other hand many others who live on the margins are victims of it. Furthermore, Bauman (1998) makes this dichotomy even sharper and makes it partly responsible for the fear and uncertainty that have now arisen within societies. 


\section{QALAAI ZANISTSCIENTIFIC JOURNAL \\ A Scientific Quarterly Refereed Journal Issued by Lebanese French University - Erbil, Kurdistan, Iraq \\ Vol. (6), No (3), Summer 2021 \\ ISSN 2518-6566 (Online) - ISSN 2518-6558 (Print)}

Moreover, Bauman (1998) points out a new fullness of our planet. In the first place, this fullness is reflected in increasing economic migration worldwide. Part of the world's population has become modern, partly thanks to colonial concerns, and can now move on. The consequence of this is that "old" moderns, those who have been modern for decades have to learn to tolerate living together with the new moderns who move to their regions via economic migration. This means that in this contact the cultural differences that previously mainly occurred between societies, now also manifest themselves within societies. Moreover, almost everyone in the world has now become modern and the chances of elimination have been scaled down.

Indeed, one of the darkest consequences of globalization is the disruption of wars: these are often led today by groups separate from states. When these groups enforce state laws after their victory, the population ends up in a disempower space. Then, part of the population who comes to the West, the so-called promised land and remains stateless.

Nevertheless, economic migrants and refugees live together in a capitalist society under the influence of a new power elite dominating the global era. However, at an urban level, this dichotomy is also being seen between a global elite and a local group that meets each other on an ethnic basis. Thus, it is obvious that globalization did not lead to a global society but a capitalist society in a post-world however, this system remains dominant in the current and next era.

Next, according to Hall, Held \& McGrew (1992) states succeed in emancipating themselves through cooperation and collaboration. However, the pursuit of national interests within these structures ensures that states acquire more real control over their national future. Besides, globalization ensures connexions among states for a mutual connection. These scholars also argue that currently people are forced to think about a world that goes beyond the entire global, regional, transnational, national, and local world (Hall, Held \& McGrew, 1992).

The scholar McGrew (1992) also discusses the model of a "bifurcated world". He argues that a final vision of how the globalized world and humanity could go hand in 


\section{QALAAI ZANISTSCIENTIFIC JOURNAL \\ A Scientific Quarterly Refereed Journal Issued by Lebanese French University - Erbil, Kurdistan, Iraq \\ Vol. (6), No (3), Summer 2021 \\ ISSN 2518-6566 (Online) - ISSN 2518-6558 (Print)}

hand includes the model of a "bifurcated world" created by the global diffusion of techno-industrial society. He mentions that thinkers such as Auguste Comte and James N. Rosenau argue that there is not one global society, but the world today is divided into a "multi-centric world" and a "state-centric world". Some examples of the latter are transnational organizations (such as Greenpeace), transnational problems (such as AIDS), transnational events (such as the publication of Salman Rushdie's Satanic Verses (1988), transnational communities based on religion, knowledge, lifestyles, cultures, ideologies, but also transnational structures related to financial products.

This multicentre world cooperates with the "society of states" where diplomatic and national power is the main force. Besides, these societies of states have their norms, structures, and principles, whereby they relate to each other in an unstable and indefinite relationship. Further, Rosenau states that we are in "the age of postinternational politics" in which there is a decentralization of power and action (Hall, Held \& McGrew 1992, 82).

Furthermore, Bauman's view is most in line with this latter model, but he sees Rosenaus' decentralization as negative and related to the division between power and politics. Bauman defines power as the ability to make things happen and concerning politics, he refers it to as the ability to decide what to do. As already mentioned, many nation-states fail to attain military, economic, and cultural sovereignty. This causes their power to be transferred to the global sphere while the state in the open global society today loses its power and its political bravery. Moreover, power obtains a dimension of uncertainty due to the lack of political controllability and in this way, their politics become less relevant due to the absence of power. It can be concluded that Bauman perceives that late modern society is subject to global forces. The phenomenon of "globalization" has created a dichotomy between a global elite and local marginalized individuals. 


\section{QALAAI ZANISTSCIENTIFIC JOURNAL \\ A Scientific Quarterly Refereed Journal Issued by Lebanese French University - Erbil, Kurdistan, Iraq \\ Vol. (6), No (3), Summer 2021 \\ ISSN 2518-6566 (Online) - ISSN 2518-6558 (Print)}

\section{CONCLUSION}

In conclusion, and to answer the main question this article discussed Zygmunt Bauman's analysis of late modernity, the phenomenon of "globalization" and the impact of globalization on the relationship between the individual and the community. Modernity called "fluid" by Bauman, begin in Western culture in the mid1970s and has challenged the truths and institutions. The latter is still there but no longer in their original, universal, and timeless form, as it was in the time of Enlightenment. Furthermore, wherein "solid" modernity the highest goal was perfection and the ultimate goal was projected onto the history, today the following applies "change is the only permanence, and uncertainty the only certainty". Nowadays, to be modern means to be on the move. Therefore, individuals participate with each other in a hopeless struggle for life. As a result, nowadays our society no longer forms a whole but is increasingly seen as a "network".

However, since 1989, the phenomenon of "globalization" has entered all levels of society and an era emerges in which temporal and spatial distances were definitively connected. Bauman sees late modern society changing mainly due to the influence of global forces. For example, he sees a decrease in the centralized power of nationstates, which caused a furor in modernity. In line with this, social stratification is also being redesigned: the phenomenon of "globalization" in the west resulted in increasing contact with "the other", namely with refugees and economic migrants. These changes entailed a dichotomy that manifests itself not only globally but also locally, especially but not exclusively in the big cities on one side a mobile, global gentry and on the other side a local, immobile group. 


\section{QALAAI ZANISTSCIENTIFIC JOURNAL \\ A Scientific Quarterly Refereed Journal Issued by Lebanese French University - Erbil, Kurdistan, Iraq \\ Vol. (6), No (3), Summer 2021 \\ ISSN 2518-6566 (Online) - ISSN 2518-6558 (Print)}

\section{BIBLIOGRAPHY:}

1. Arendt, H. (2013). The human condition. University of Chicago Press.

2. Bauman, Z. (1998). Globalization: The Human Consequences (Cambridge, England: Polity).

3. Bauman, Z. (2013). Liquid love: On the frailty of human bonds. John Wiley \& Sons.

4. Bauman, Z. (2013). Liquid modernity. John Wiley \& Sons.

5. Bauman, Z. (2018). Vloeibare tijden: Leven in een eeuw van onzekerheid. Klement, Uitgeverij.

6. Bauman, Z., \& May, T. (2019). Thinking sociologically. John Wiley \& Sons.

7. Beck, U., 2002. The cosmopolitan society and its enemies. Theory, culture \& society, 19(12), pp.17-44.

8. Cladis, M. S. (1989). Durkheim's communtarian defense of liberalism. Soundings, 275295.

9. d'Alleva, A. (2005). Methods and theories of art history. Laurence King Publishing.

10. Eddy, E. M., \& Partridge, W. L. (Eds.). (1987). Applied anthropology in America. Columbia University Press.

11. Elliott, A. (2014). Contemporary social theory: An introduction. Routledge.

12. Elliott, A. (2015). Identity troubles: An introduction. Routledge.

13. Hall, S., Held, D., \& McGrew, A. G. (1992). Modernity and its Futures.

14. Lee, R. L. (2005). Bauman, liquid modernity and dilemmas of development. Thesis Eleven, 83(1), 61-77.

15. Morgenthau, H. J., Thompson, K. W., \& Clinton, W. D. (1985). Politics among nations: The struggle for power and peace.

\section{تاك و كوّمهلّكا له موّديرنيتى شله لهلايهن زيگمونت باومان}

لهوانهيه بوّ زوّر كه موّديّرن شل بيروّكهيه نوى نوى بيّت. به يِيّى بوّجوونى كوّمهلّناس و فهيله سووفى بهريتانى/يوّلهندى زيكمونت باومان كوّمهلكَا موّديّرنهكان له تواندنهوهدان و شولدهبنهوه. له بهرههمه كهيدا باومان نهمانى ييّكهاتهى يتهو و دامهزراوهكان شيدهكاتهوه، كه بناغهى كوّمهلّاى بولى

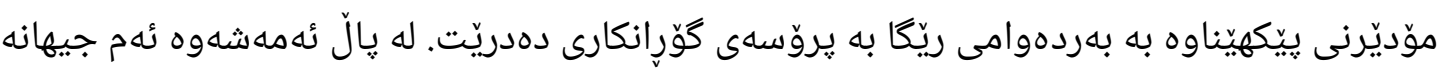
شله ههرگيز دريّزايهتيراناگريّت و تايبهتمهندى رِاوهستانى نييه. وا دياره ههموو شتيّك له گوّرانكاريدايه 


\section{QALAAI ZANISTSCIENTIFIC JOURNAL}

A Scientific Quarterly Refereed Journal Issued by Lebanese French University - Erbil, Kurdistan, Iraq

Vol. (6), No (3), Summer 2021

ISSN 2518-6566 (Online) - ISSN 2518-6558 (Print)

وهك ئهو موّدهيانهى، كه يُيّمهمانان بهدواى كهوتووين و ئهو تيّكنهلوَزيايهى بهكارى دههيّنين و ئهو

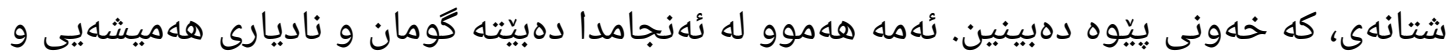

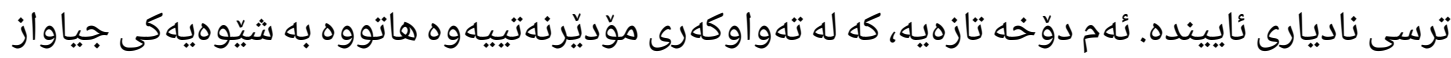

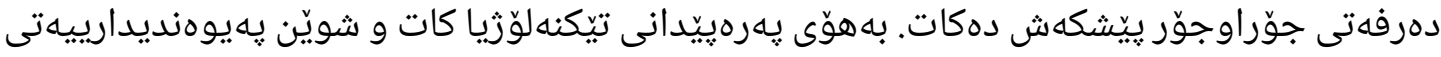

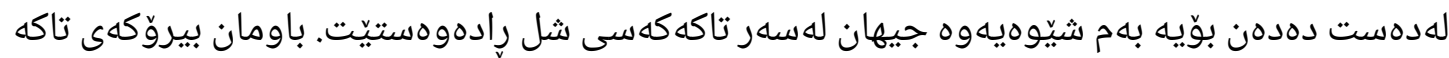

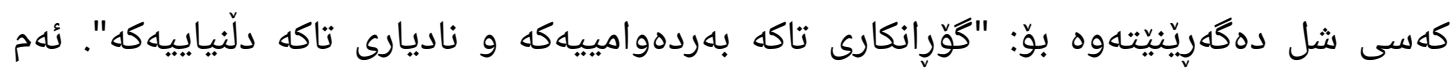

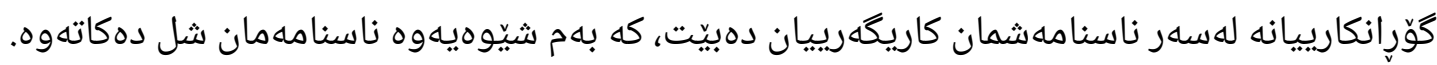

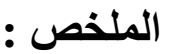

مفهوم الحداثة السائلة وفقا لعالم الاجتماع البريطاني البولندي الأصل ان المجتمع الحديث في حالة ذوبان و اصبح سائلا، ويعرف هذا الأخير بمفهوم (الحداثة السائلة).

وفي عمله يحلل بومان البناءات و المؤسسات الصلبة التي شكلت أساس المجتمع الحديث، و و التي فسحت الطريق

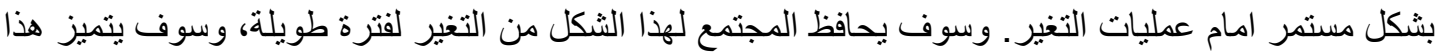

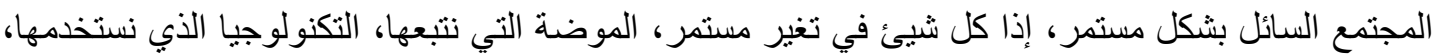

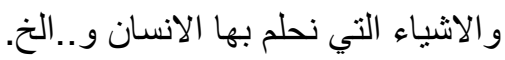

و هذا يؤدي الى عدم اليقين و الخوف المستمر الذي يخبئه المستقبل. وبهذا الشكل كما يقول بومان هذا النظام الجديد

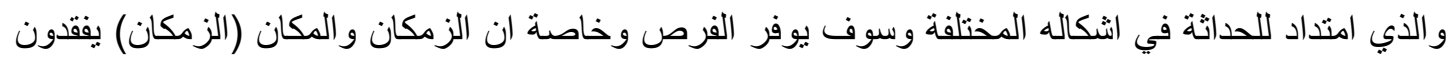

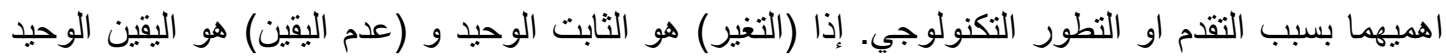
بومان

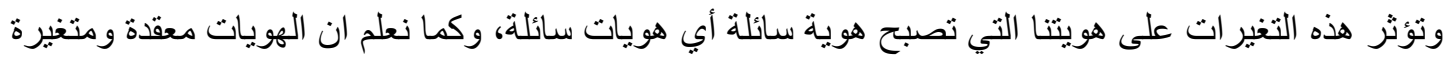

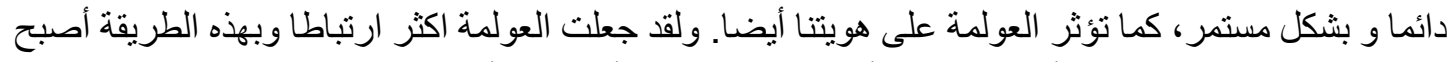

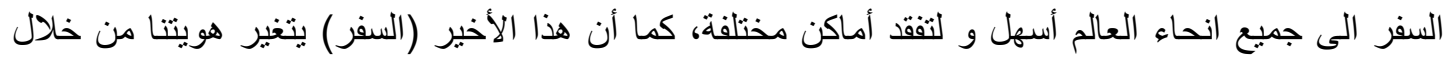

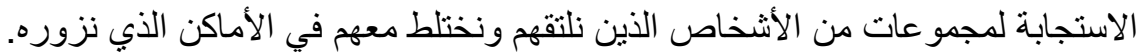

